\title{
Pengaruh strukture aktiva, profitabilitas, pertumbuhan penjualan, dan size perusahaan terhadap struktur modal pada perusahaan makanan dan minuman yang terdaftar di BEI periode 2014-2018
}

\section{Indiani Sembiring*; Susi L. Sitinjak; Debi Herdina Hutabarat; Siti Aisyah Nasution}

\author{
Prodi Akuntansi, Fakultas Ekonomi, Universitas Prima Indonesia, Medan \\ *E-mail korespondensi : indianisembiring@gmail.com
}

\begin{abstract}
This study aims to determine and test the effect of assets structure, profitability, sales growth, and firm size on capital structure partially and simultaneously of food and beverage companies. Determination of the sample used in this study was purposive sampling technique which amounted to 11 companies with a year observation of five years and data obtained from the financial statements of food and beverage companies at www.idx.co.id. The data analysis method used is multiple linear regression analysis. Based on the results obtained that assets structure has a significant effect on capital structure. Meanwhile, profitability, sales growth, and firm size didn't have a significant effect on capital structure. Simultaneous hypothesis test results obtained that the assets structure, profitability, sales growth, and firm size have a significant effect on capital structure.
\end{abstract}

Keywords: Assets structure, Profitability, Sales growth, Firm size, Capital structure

\begin{abstract}
Abstrak
Penelitian ini bertujuan mengetahui pengaruh parsial dan simultan struktur aktiva, profitabilitas, pertumbuhan penjualan, dan size perusahaan terhadap struktur modal pada perusahaan makanan dan minuman di Bursa Efek Indonesia. Penentuan sampel pada penelitian ini adalah dengan teknik purposive sampling yang berjumlah 11 perusahaan dengan tahun pengamatan lima tahun dan data yang diperoleh dari laporan keuangan Perusahaan Makanan dan Minuman dii www.idx.co.id. Metode analisis data yang digunakan adalah analisis regresi linier berganda. Hasil penelitian ini menunjukan bahwa struktur aktiva berpengaruh signifikan terhadap struktur modal. Sedangkan, profitabilitas, pertumbuhan penjualan, dan size perusahaan tidak berpengaruh signifikan terhadap struktur modal. Hasil uji hipotesis simultan diperoleh bahwa struktur aktiva, profitabilitas, pertumbuhan penjualan, dan size perusahaan berpengaruh signifikan terhadap struktur modal.
\end{abstract} Kata kunci: Struktur aktiva, Profitabilitas, Pertumbuhan penjualan, Size perusahaan,
Struktur modal

\section{PENDAHULUAN}

Struktur modal merupakan komposisi sumber pendanaan (funding) perusahaan dalam jangka panjang yang terdiri atas utang jangka panjang, saham biasa dan saldo laba. Penggunaan atas sumber dana tersebut pada kegiatan operasional perusahaan akan secara 
langsung berdampak terhadap munculnya biaya modal. Dimana biaya modal memiliki posisi yang penting bagi manajemen perusahaan pada saat pengambilan keputusan yang berkaitan dengan struktur modal. Perbandingan dalam jangka panjang yang optimal dapat menentukan jumlah sumber modal yang selanjutnya akan membentuk jumlah modal yang optimal, yaitu struktur modal yang memaksimumkan nilai perusahaan atau harga saham dan meminimumkan biaya modal. Adapun variabel yang mempengaruhi struktur modal tersebut anatara lain profitabilitas, pertumbuhan penjualan, size perusahaan dan struktur aktiva (Laga, 2016).

Struktur aktiva pada perusahaan memiliki pengaruh langsung terhadap sumber pembelanjaan perusahaan. Perusahaan yang memiliki aktiva tetap dengan jumlah yang cukup besar dapat menggunakan utang relatif besar juga. Hal tersebut diakibatkan oleh skala perusahaan yang besar akan mempermudah perusahaan mendapatkan akses sumber pendanaan (funding) dibandingkan perusahaan yang realtif kecil. Selanjutnya besarnya aktiva tetap perusahaan juga dapat digunakan sebagai jaminan atas utang perusahaan (Joni dan Lina, 2010). Menurut theory pecking order bahwa saat perusahaan mempunyai aktiva berwujud yang relatif lebih besar, maka penilaian atas aktiva akan semakin mudah. Oleh karena itu, permasalahan terkait asimetri informasi menjadi lebih rendah, yang membuat perusahaan mengurangi penggunaan utang saat proporsi aktiva berwujud akan mengalami peningkatan.

Profitabilitas perusahaan sangat berkaitan dengan keberhasilan atau realisasi atas kebijakan dan kinerja keuangan perusahaan. Perusahaan yang mampu melaksanakan kinerja keuangan yang baik akan memiliki tingkat pengembalian tinggi atas investasi dengan tingkat penggunaan utang yang relatif kecil. Tingkat pengembalian yang tinggi memberikan peluang kepada perusahaan untuk mendapatkan sumber pendanaan (funding) relatif besar yang berdampak langsung terhadap perubahan struktur modal perusahaan (Kartika 2009). Selaras dengan pendapat dari Sawir (2005) bahwa perusahaan yang memiliki tingkat profitabilitas tinggi cenderung menggunakan utang dalam jumlah relatif lebih kecil, karena tingkat pengembalian yang relatif tinggi memungkinkan perusahaan akan menggunakan permodalan melalui laba ditahan.

Perusahaan yang mampu meningkatkan pertumbuhan penjualan yang tinggi, maka akan berdampak terhadap kondisi keuangan perusahaan akan membaik. Disamping hal tersebut peningkatan pertumbuhan penjualan perusahaan akan mempengaruhi peningkatan atas sumber pendanaan (funding) perusahaan, serta berpengaruh terhadap perubahan tingkat struktur modal perusahaan (Laga, 2016). Menurut Naibaho, dkk (2015) bahwa pertumbuhan penjualan yang tinggi akan menjadi salah satu pertimbangan bagi suatu perusahaan untuk menentukan jumlah utang. Semakin tinggi penjualan perusahaan, maka semakin tinggi keuntungan yang diperoleh perusahaan, sehingga keuntungan tersebut menjadi tambahan modal bagi perusahaan untuk melakukan pengembangan yang tentunya akan membutuhkan utang yang semakin besar.

Tingkat besar atau kecil size (ukuran) perusahaan akan dapat mempengaruhi secara langsung terhadap keputusan manajemen dalam memutuskan pendanaan yang akan dipakai untuk operasional perusahanya. Perusahaan dengan ukuran yang besar akan cenderung menggunakan utang dalam jangka panjang lebih besar dibandingkan dengan perusahaan yang lebih kecil hal ini berarti menunjukan adanya hubungan antara ukuran perusahaan dengan struktur modal (Kartika, 2009). Menurut Alvareza dan Topowijono (2017) bahwa size perusahaan adalah salah satu faktor pertimbangan perusahaan dalam menentukan kebijakan atas keputusan pendanaan perusahaan. Semakin besar size perusahaan akan membutuhkan pengeluaran dana semakin besar, baik itu melalui kebijakan utang atau modal sendiri dalam mempertahankan dan mengembangkan perusahaan. 
Tabel 1. Fenomena penelitian struktur aktiva terhadap struktur modal

\begin{tabular}{cccccc}
\hline $\begin{array}{c}\text { Kode } \\
\text { Emiten }\end{array}$ & Tahun & $\begin{array}{c}\text { Aktiva } \\
\text { Tetap } \\
\text { (juta) }\end{array}$ & $\begin{array}{c}\text { Utang } \\
\text { (juta) }\end{array}$ & Aktiva Tetap & Utang \\
\hline \multirow{4}{*}{ INDF } & 2014 & $22,011,488$ & $44,710,509$ & - & - \\
& 2015 & $25,096,342$ & $48,709,933$ & 14.01 & 8.95 \\
& 2016 & $25,701,913$ & $38,233,092$ & 2.41 & -21.51 \\
& 2017 & $29,787,303$ & $41,182,764$ & 15.90 & 7.71 \\
& 2018 & $42,050,257$ & $47,435,443$ & 41.17 & 15.18 \\
\hline
\end{tabular}

Sumber: Bursa Efek Indonesia, 2019(diolah)

Berdasarkan data pada Tabel 1 menunjukkan bahwa PT Indofood Sukses Makmur, Tbk (INDF) pada tahun 2014-2015 aktiva tetap mengalami peningkatan sebesar $14.01 \%$ sementara utang perusahaan mengalami peningkatan sebesar $8.95 \%$, dari data tersebut menunjukkan bahwa bila aktiva tetap meningkat, maka utang mengalami peningkatan. Aktiva tetap dalam perusahaan makanan dan minuman dapat berupa tanah, mesin, dan bangunan relatif besar yang dapat digunakan sebagai jaminan utang, hal tersebut yang menyebabkan perusahaan cenderung akan menggunakan modal asing atas struktur modalnya. Selaras dengan pendapat Kartika (2016) bahwa perusahaan yang mempunyai aktiva yang relatif besar akan menggunakan aktiva sebagai jaminan dalam mendapatkan utang dari pihak luar. Hal ini tidak selaras dengan pendapat Priambodo dkk (2014) menyatakan struktur aktiva meningkat, maka diikuti penurunan struktur modal.

Tabel 2.Fenomena penelitian profitabilitas terhadap struktur modal

\begin{tabular}{|c|c|c|c|c|c|}
\hline \multirow{2}{*}{$\begin{array}{c}\text { Kode } \\
\text { Emiten }\end{array}$} & \multirow{2}{*}{ Tahun } & \multirow{2}{*}{$\begin{array}{l}\text { Laba } \\
\text { (juta) }\end{array}$} & \multirow{2}{*}{$\begin{array}{l}\text { Utang } \\
\text { (juta) }\end{array}$} & \multicolumn{2}{|c|}{ Kenaikan/Penurunan (\%) } \\
\hline & & & & Laba & Utang \\
\hline \multirow{5}{*}{ MYOR } & 2014 & 409,825 & $4,100,555$ & & \\
\hline & 2015 & $1,250,233$ & $5,194,460$ & 205.07 & 26.68 \\
\hline & 2016 & $1,388,676$ & $6,265,256$ & 11.07 & 20.61 \\
\hline & 2017 & $1,630,954$ & $7,354,346$ & 17.45 & 17.38 \\
\hline & 2018 & $1,128,458$ & $7,861,408$ & -30.81 & 6.89 \\
\hline
\end{tabular}

Sumber: Bursa Efek Indonesia, 2019(diolah)

PT Mayora Indah, Tbk (MYOR) menunjukkan laba bersih mengalami peningkatan pada tahun 2014-2015 sebesar $205.07 \%$ sementara utang mengalami peningkatan sebesar $26.68 \%$, yang berarti peningkatan pada laba bersih akan meningkatkan tingkat utang. Peningkatan pada laba bersih selaras dengan penjualan perusahaan yang meningkat. Tingkat pengembalian yang tinggi tidak menjamin perusahaan melakukan pendanaan atas laba yang diperoleh perusahaan, melainkan menggunakan utang. Sehingga membuat jumlah utang mengalami peningkatan. Selaras dengan pendapat Kartika (2016) bahwa perusahaan yang cukup menguntungkan dalam suatu industri yang sama akan cenderung memiliki tingkat utang relatif tinggi. Hal tersebut tidak selaras dengan pendapat dari Priambodo dkk (2014) bahwa profitabilitas meningkat, akan mampu menurunkan tingkat struktur modal perusahaan.

Tabel 3. Fenomena penelitian pertumbuhan penjualan terhadap struktur modal

\begin{tabular}{cccccc}
\hline $\begin{array}{c}\text { Kode } \\
\text { Emiten }\end{array}$ & Tahun & $\begin{array}{c}\text { Penjualan } \\
\text { (juta) }\end{array}$ & \multirow{2}{*}{$\begin{array}{c}\text { Utang } \\
\text { (juta) }\end{array}$} & \multicolumn{2}{c}{ Kenaikan/Penurunan (\%) } \\
\cline { 6 - 6 } \cline { 5 - 6 } INDF & 2014 & $63,594,452$ & $44,710,509$ & Penjualan & Utang \\
\hline & 2015 & $64,061,947$ & $48,709,933$ & - & - \\
& 2016 & $66,659,484$ & $38,233,092$ & 4.74 & 8.95 \\
& 2017 & $70,186,618$ & $41,182,764$ & 5.29 & -21.51 \\
& 2018 & $54,742,187$ & $47,435,443$ & -22.00 & 15.18 \\
\hline
\end{tabular}

Sumber: Bursa Efek Indonesia, 2019(diolah) 
Tingkat pertumbuhan penjualan PT Indofood Sukses Makmur, Tbk (INDF) mengalami peningkatan tahun 2016-2017 sebesar 5.29\% sementara struktur modal mengalami peningkatan sebesar $7.71 \%$, yang berarti bawah penjualan mengalami peningkatan akan mampu meningkatkan utang. Perusahaan dalam meningkatan jumlah atau kapasitas produksi sebagai dampak terhadap peningkatan penjualan perusahaan membutuhkan atau melibatkan utang atas aktivitas tersebut. Selaras dengan pendapat Halim dalam Zuliani (2014) bahwa perusahaan yang mempunyai pertumbuhan relatif tinggi akan cenderung menggunakan utang yang relatif lebih besar. Hal tersebut tidak selaras dengan pendapat dari Maryanti (2016) menyatakan bahwa pertumbuhan penjualan (perusahaan) meningkat akan diikuti penurunan yang terjadi pada struktur modal.

Tabel 4. Fenomena penelitian size perusahaan terhadap struktur modal

\begin{tabular}{|c|c|c|c|c|c|}
\hline \multirow{2}{*}{$\begin{array}{l}\text { Kode } \\
\text { Emiten }\end{array}$} & \multirow{2}{*}{ Tahun } & \multirow{2}{*}{$\begin{array}{c}\text { Aktiva } \\
\text { (juta) }\end{array}$} & \multirow{2}{*}{$\begin{array}{c}\text { Utang } \\
\text { (juta) }\end{array}$} & \multicolumn{2}{|c|}{ Kenaikan/Penurunan (\%) } \\
\hline & & & & Aktiva & Utang \\
\hline \multirow{5}{*}{ ULTJ } & 2014 & $2,917,084$ & 651,986 & - & - \\
\hline & 2015 & $3,539,996$ & 742,490 & 21.35 & 13.88 \\
\hline & 2016 & $4,239,200$ & 749,966 & 19.75 & 1.01 \\
\hline & 2017 & $5,186,940$ & 978,185 & 22.36 & 30.43 \\
\hline & 2018 & $5,584,546$ & 890,042 & 7.67 & -9.01 \\
\hline
\end{tabular}

Sumber: Bursa Efek Indonesia, 2019(diolah)

Tingkat size perusahaan PT Ultrajaya Milk Industry and Trading Company, Tbk menunjukkan aktiva tahun 2014-2015 mengalami peningkatan sebesar $21.35 \%$ dan akan diikuti peningkatan utang sebesar $13.88 \%$. Jumlah aktiva yang dimiliki perusahaan dapat mengambarkan besaran ukuran perusahaan, perusahaan yang besar akan cenderung mempunyai sumber pendanaan relatif besar yang bersumber dari utang perusahaan. Selaras dengan pendapat Kartika (2016) bahwa perusahaan besar akan cenderung mempunyai kebutuhan dana yang relatif besar, sehingga salah satu alternatif pemenuhan dana perusahaan menggunakan dana eksternal (utang). Hal tersebut tidak selaras dengan pendapat dari Kartika (2016) menyatakan bahwa ukuran (size) perusahaan yang mengalami peningkatan akan menurunkan struktur modal perusahaan.

Berdasarkan latar belakang masalah di atas yang telah dijelaskan dengan menggunakan data empiris beberapa perusahaan Makanan dan Minuman di Bursa Efek Indonesia menunjukkan adanya inkonsistensi dengan teori atau penelitian terdahulu yang sebelumnya telah membahas mengenai topik tersebut, sehingga mendorong peneliti untuk membahas judul penelitian "Pengaruh struktur aktiva, profitabilitas, pertumbuhan penjualan, dan size perusahaan terhadap struktur modal pada perusahaan makanan dan minuman yang terdaftar di Bursa Efek Indonesia Periode 2014-2018".

\section{LANDASAN TEORI}

\section{Struktur modal}

Struktur modal adalah perimbangan antara utang dan modal yang mampu mencerminkan dari pembelanjaan permanen. Keputusan atas pendanaan terkait dengan struktur modal perusahaan, karena struktur modal sangat menentukan bagaimana suatu keputusan ditetapkan oleh perusahaan, apakah perusahaan lebih cenderung menggunakan dana internal ataupun lebih menggunakan dana eksternal (Riyanto, 2010). Menurut Brigham dan Houston (2015) bahwa tingkat struktur modal dapat diproksikan menjadi rasio solvabilitas (debt to equity ratio). Adapun rumus pengukuran debt to equity ratio adalah: 


$$
\text { Debt to Equity Ratio }=\frac{\text { Total utang }}{\text { Modal sendiri }}
$$

\section{Struktur aktiva}

Struktur Aktiva atau struktur kekayaan adalah perimbangan atau perbandingan baik dalam artian absolut maupun dalam artian relatif antara aktiva lancar dengan aktiva tetap, yang dimaksud dengan artian absolut adalah perbandingan dalam bentuk nominal, sedangkan yang dimaksud dengan relatif adalah perbandingan dalam bentuk persentase (Riyanto, 2010). Semakin tinggi struktur aktiva (yang berarti semakin besar aktiva tetap) maka penggunaan modal sendiri akan semakin tinggi (modal asing semakin sedikit) dengan kata lain struktur modalnya semakin rendah (Prabansari dan Kusuma dalam Zuliani, 2014).

$$
\text { Struktur Aktiva }=\frac{\text { Aktiva Tetap }}{\text { Total Aktiva }}
$$

\section{Profitabilitas}

Rasio profitabilitas adalah rasio yang digunakan untuk menilai kemampuan perusahaan dalam mencari keuntungan. Rasio ini juga memberikan ukuran tingkat efektifitas manajemen suatu perusahaan (Kasmir, 2013). Rasio profitabilitas akan diproksikan kedalam Return on Asset (ROA) yang memiliki arti kemampuan suatu erusahaan untuk menghasilkan laba bersih berdasarkan tingkat aktiva yang tertentu. Return on Asset (ROA) akan menunjukkan kemampuan dari sumber daya ekonomis yang diinvestasikan dalam semua aktiva untuk menghasilkan laba bersih.

$$
\text { Return On Assets }=\frac{\text { Laba Bersih }}{\text { Total Aktiva }}
$$

\section{Pertumbuhan penjualan}

Pertumbuhan atas penjualan adalah indikator yang penting dari penerimaan pasar atas produk yang dihasilkan perusahaan, pendapatan yang diperoleh melalui penjualan akan digunakan dalam mengukur tingkat pertumbahan penjualan berdasarkan periode tertentu (Swastha dan Handoko, 2011). Perusahaan memiliki pertumbuhan penjualan tinggi akan mampu memenuhi kewajiban finansialnya seandainya perusahaan tersebut membelanjai aktiva dengan utang, begitu pula sebaliknya. Pengukuran pertumbuhan penjualan dengan membandingkan penjualan pada tahun $t$ setelah dikurangi penjualan pada periode sebelumnya terhadap penjualan pada periode sebelumnya (Kusuma dalam Zuliani, 2014)

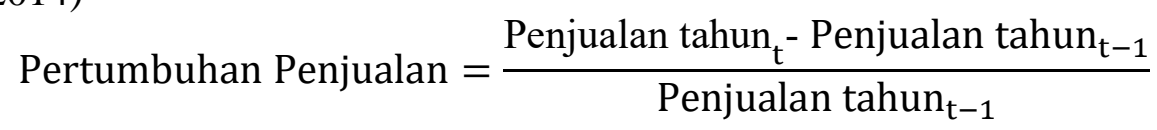

\section{Size perusahaan}

Ukuran perusahaan akan menggambarkan besar kecilnya suatu perusahaan yang ditunjukkan oleh total aktiva. Jadi, ukuran perusahaan merupakan ukuran atau besarnya asset yang dimiliki oleh perusahaan (Sujianto dalam Sekartaji, 2017). Menurut Niresh dan Velnampy (2014) bahwa ukuran perusahaan merupakan faktor yang utama dalam menentukan profitabilutas dari suatu perusahaan dengan konsep yang dikenal skala ekonomi, perusahaan dengan ukuran besar membeli bahan baku (input produksi) dalam jumlah yang besar sehingga perusahaan akan mendapat potongan harga (quantity discount) lebih banyak dari pemasok Pengukuran perusahaan menggunakan nilai logaritma atas total aktiva yang dimiliki perusahaan, dengan formulasi sebagai berikut: 


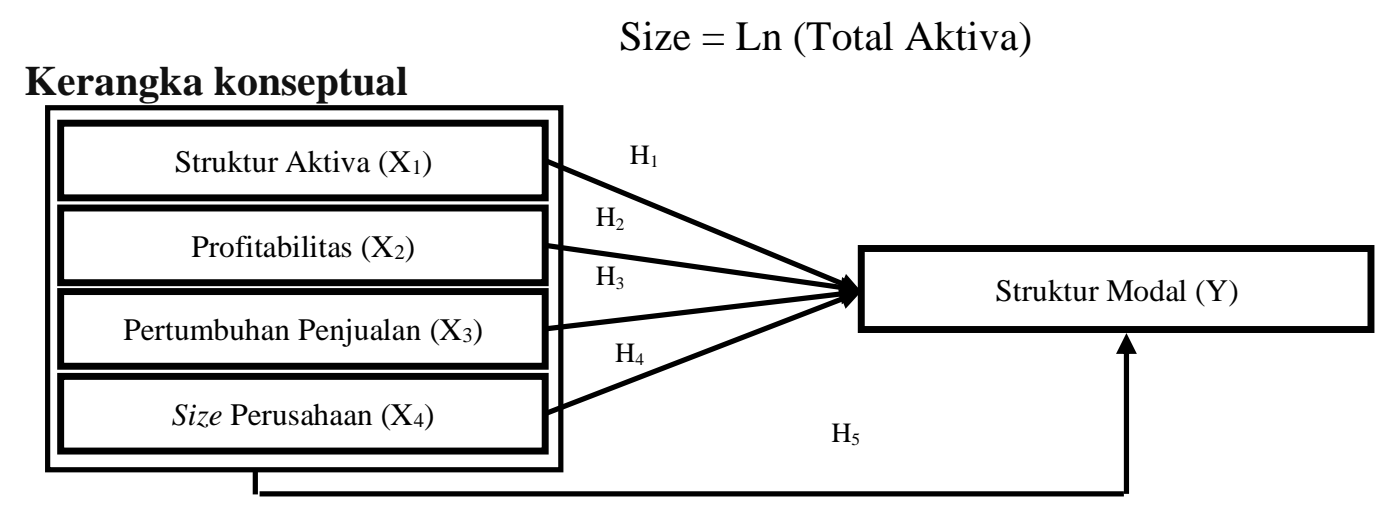

Gambar 1. Kerangka konseptual

\section{Hipotesis}

1. $\mathrm{H}_{1}$ : Struktur Aktiva berpengaruh terhadap Struktur Modal.

2. $\mathrm{H}_{2}$ : Profitabilitas berpengaruh terhadap Struktur Modal.

3. $\mathrm{H}_{3}$ : Pertumbuhan Penjualan berpengaruh terhadap Struktur Modal.

4. $\mathrm{H}_{4}$ : Size Perusahaan berpengaruh terhadap Struktur Modal.

5. $\mathrm{H}_{5}$ :Struktur Aktiva, dan Profitabilitas Pertumbuhan Penjualan, dan Size Perusahaan berpengaruh terhadap Struktur Modal Perusahaan.

\section{METODE}

Jenis penelitian ini menggunakan metode asosiatif dengan pendekatan kuantitatif. Menurut Juliandi (2013) penelitian dengan permasalahan asosiatif adalah penelitian yang memiliki upaya untuk mengkaji suatu variabel memiliki keterkaitan dan berhubungan dengan variabel lain, atau apakah suatu variabel menjadi penyebab perubahan dari variabel lainnya.

Data yang digunakan dalam penelitian ini adalah data sekunder. Data sekunder merupakan data yang diperoleh dari pihak kedua yang bersumber dari laporan keuangan Perusahaan Makanan dan Minuman yang Terdaftar di Bursa Efek Indonesia tahun 20142018 yang diakses di www.idx.co.id.

\section{Populasi dan sampel}

Populasi pada penelitian ini adalah seluruh Perusahaan Makanan dan Minuman yang Terdaftar di Bursa Efek Indonesia tahun 2014-2018 sebanyak 18 perusahaan. Sampel yang digunakan dalam penelitian ini ditentukan adalah purposive sampling. Metode ini digunakan untuk memperoleh sampel yang representatif. Kriteria-kriteria sampel yang digunakan dalam penelitian ini pada Tabel 5 berikut.

Tabel 5. Kriteria pengambilan sampel penelitian

\begin{tabular}{lc}
\hline \multicolumn{1}{c}{ Kriteria } & Sampel \\
\hline 1. Perusahaan tercatat dan terdaftar di Bursa Efek Indonesia & 18 \\
tahun 2014-2018 & (5) \\
2. Perusahaan makanan dan minuman yang tidak \\
mempublikasikan laporan keuangan yang telah di audit \\
periode tahun 31 desember 2014-31 desember 2018 \\
$\begin{array}{l}\text { 3. Perusahaan tidak memiliki keuntungan atau laba positif } \\
\text { selama tahun 2014-2018 }\end{array}$ \\
\hline Total sampel tahun 2014-2018 \\
\hline
\end{tabular}

Sumber : Data diolah, 2020 
Berdasarkan kriteria di atas menghasilkan 11 (sebelas) emiten yang dapat digunakan menjadi sampel penelitian pada Tabel 6 berikut.

Tabel 6. Sampel penelitian

\begin{tabular}{ccl}
\hline No & Kode & \multicolumn{1}{c}{ Nama Perusahaan } \\
\hline 1 & CEKA & PT Wilmar Cahaya Indonesia Tbk \\
2 & DLTA & PT Delta Djakarta Tbk \\
3 & ICBP & PT Indofood CBP Sukses Makmur Tbk \\
4 & INDF & PT Indofood Sukses Makmur Tbk \\
5 & MLBI & PT Multi Bintang Indonesia Tbk \\
6 & MYOR & PT Mayora Indah Tbk \\
7 & ROTI & PT Nippon Indosari Corporindo Tbk \\
8 & SKBM & PT Sekar Bumi Tbk \\
9 & SKLT & PT Sekar Laut Tbk \\
10 & STTP & PT Siantar Top Tbk \\
11 & ULTJ & PT Ultrajaya Milk Industry and Trading Company Tbk
\end{tabular}

Sumber : Data diolah, 2020

Penentuan sampel melalui kriteria yang telah ditentukan, maka sampel dalam penelitian ini sebesar 11 perusahaan dan tahun pengamatan sebesar 5 (lima) tahun, dengan diperoleh jumlah keseluruhan data sebesar 55 data (11 x 5 tahun).

\section{Definisi operasional}

Definisi operasional adalah sub-bagian pada penelitian yang mendeskripsikan tentang ukuran dari setiap variabel penelitian.

Tabel 7. Definisi operasional

\begin{tabular}{|c|c|c|c|}
\hline Variabel & Definisi operasional & Pengukuran & Skala \\
\hline $\begin{array}{l}\text { Struktur } \\
\text { Aktiva } \\
\left(\mathrm{X}_{1}\right)\end{array}$ & $\begin{array}{l}\text { Perimbangan antara } \\
\text { tetap terhadap total aktiva } \\
\text { (Riyanto, 2010) }\end{array}$ & Struktur Aktiva $=\frac{\text { Aktiva Tetap }}{\text { Total Aktiva }}$ & Rasio \\
\hline $\begin{array}{c}\text { Profitabilitas } \\
\qquad\left(\mathrm{X}_{2}\right)\end{array}$ & $\begin{array}{l}\text { Kemampuan perusahaan dalam } \\
\text { memperoleh laba atas } \\
\text { penggunaan aktiva yang } \\
\text { dimilikinya (Kasmir, 2013) }\end{array}$ & $\mathrm{ROA}=\frac{\text { Laba Bersih }}{\text { Total Aktiva }}$ & Rasio \\
\hline $\begin{array}{l}\text { Pertumbuhan } \\
\text { Penjualan } \\
\left(\mathrm{X}_{3}\right)\end{array}$ & $\begin{array}{l}\text { Untuk mengukur tingkat } \\
\text { kesehatan perusahaan melalui } \\
\text { kegiatan penjualannya } \\
\text { (Swastha dan Handoko, 2011) }\end{array}$ & Growth $=\frac{\text { P. } \operatorname{tahun}_{\mathrm{t}}-\mathrm{P}_{\mathrm{tahun}} \mathrm{t}-1}{\text { P. } \operatorname{tahun}_{\mathrm{t}-1}}$ & Rasio \\
\hline $\begin{array}{l}\text { Size } \\
\text { Perusahaan } \\
\quad\left(\mathrm{X}_{4}\right)\end{array}$ & $\begin{array}{l}\text { Ukuran besar atau kecilnya } \\
\text { perusahaan melalui total aktiva } \\
\text { yang dimiliki (Sujianto dalam } \\
\text { Sekartaji, 2017) }\end{array}$ & Size $=$ Ln $($ Total Aktiva $)$ & Rasio \\
\hline $\begin{array}{l}\text { Struktur } \\
\text { Modal } \\
\text { (Y) }\end{array}$ & $\begin{array}{l}\text { Perimbangan antara total utang } \\
\text { terhadap modal sendiri/ekuitas } \\
\text { (Riyanto, 2010) }\end{array}$ & DER $=\frac{\text { Total hutang }}{\text { Modal sendiri }}$ & Rasio \\
\hline
\end{tabular}

Sumber : Data diolah, 2020

\section{Uji asumsi klasik}

Sebelum melaksanakan analisis regresi linear berganda, maka terlebih dahulu melakukan pengujian asumsi klasik menggunakan empat pengujian, yaitu: 


\section{Uji normalitas}

Uji normalitas digunakan untuk mengetahui sebaran data penelitian terdistribusi normal atau tidak Pengujian nornalitas menggunakan grafik histogram, $P-P$ Plot, dan Kolmogorov-Smirnov Test.

\section{Uji heterokedastisitas}

Uji heterokedastisitas digunakan untuk mengetahui dan mengukur dalam model regresi terjadi ketidaksamaan atau kesamaan varians dari residual antara satu pengamatan ke pengamatan lainnya. Metode yang digunakan untuk menguji adanya gejala heterokedastisitas adalah Scatterplot dan uji Glejser.

\section{Uji multikolinearitas}

Uji multikolinearitas digunakan untuk menguji dalam model regresi terjadi korelasi antar variabel bebas. Apabila nilai Variance Inflasi Factor (VIF) $<10$ dan Tolerance $>0.10$ maka tidak terjadi korelasi antar variabel bebas.

\section{Uji autokorelasi}

Uji autokorelasi digunakan pada data time series (runtun waktu). Uji Autokorelasi bertujuan untuk menguji apakah dalam model regresi linier ada korelasi antara kesalahan pengganggu pada periode $\mathrm{t}$ dengan kesalahan pengganggu pada periode t-1 (sebelumnya). Apabila nilai Durbin-Watson (DW) termasuk dalam persamaan, yaitu $-2<\mathrm{DW}<+2$, maka tidak terjadi autokorelasi (Juliandi, 2013).

\section{Teknik analisis data}

\section{Analisis regresi linear berganda}

Analisis regresi linear berganda bertujuan untuk menunjukkan arah hubungan linier variabel Struktur Aktiva, Profitabilitas, Pertumbuhan Penjualan, dan Size Perusahaan terhadap Struktur Modal. Persamaan yang digunakan, yaitu:

$$
\mathbf{Y}=\alpha+\beta_{1} \mathbf{X}_{1}+\beta_{2} \mathbf{X}_{2}+\beta_{3} \mathbf{X}_{3}+\beta_{4} \mathbf{X}_{4}+e
$$

Keterangan:

$\mathrm{Y} \quad=$ Struktur modal

$\alpha \quad=$ Konstanta

$\beta_{1} \quad=$ Koefisien regresi variabel struktur aktiva

$\beta_{2} \quad=$ Koefisien regresi variabel profitabilitas

$\beta_{3} \quad=$ Koefisien regresi variabel pertumbuhan penjualan

$\beta_{4} \quad=$ Koefisien regresi variabel size perusahaan

$\mathrm{X}_{1} \quad=$ Struktur aktiva

$\mathrm{X}_{2} \quad=$ Profitabilitas

$\mathrm{X}_{3} \quad=$ Pertumbuhan penjualan

$\mathrm{X}_{4} \quad=$ Size perusahaan

e $\quad=$ Standar error

\section{HASIL DAN PEMBAHASAN}

\section{Statistik deskriptif}

Sampel dalam penelitian ini adalah Perusahaan Makanan dan Minuman di Bursa Efek Indonesia pada tahun 2014-2018 dengan jumlah keseluruhan data sebesar 55 data yang diperoleh dari laporan keuangan perusahaan. 
Tabel 8. Statistik deskriptif

\begin{tabular}{lrrrrr}
\hline & N & Minimum & Maximum & Mean & $\begin{array}{c}\text { Std. } \\
\text { Deviation }\end{array}$ \\
\hline Struktur Aktiva & 55 & .06 & .78 & .3554 & .16608 \\
Profitabilitas & 55 & .01 & .53 & .1230 & .10762 \\
Pertumbuhan & 55 & -.20 & .46 & .0887 & .11288 \\
Penjualan & 55 & 26.53 & 32.20 & 28.9531 & 1.51379 \\
Size Perusahaan & 55 & .16 & 3.03 & .8971 & .53655 \\
Struktur Modal & 55 & & & & \\
Valid N (listwise) & & & & &
\end{tabular}

Sumber: Data diolah, 2020

Pada Tabel 8 menunjukkan bahwa nilai minimum, nilai maksimum, mean (nilai rata-rata), dan standar deviasi seluruh variabel penelitian, yaitu: Variabel struktur aktiva memiliki jumlah sampel sebesar 55 data, dengan nilai minimum sebesar 0.06 pada PT Delta Djakarta Tbk (DLTA) tahun 2018 dan sebesar 0.78 pada PT Nippon Indosari Corporindo Tbk (ROTI) tahun 2014.

Variabel profitabilitas memiliki jumlah sampel sebesar 55 data, dengan nilai minimum sebesar 0.01 pada PT Sekar Bumi Tbk (SKBM) tahun 2018 dan sebesar 0.53 pada PT Multi Bintang Indonesia Tbk (MLBI) tahun 2017. Variabel pertumbuhan penjualan memiliki jumlah sampel sebesar 55 data, dengan nilai minimum sebesar -0.20 pada PT Delta Djakarta Tbk (DLTA) tahun 2015 dan sebesar 0.46 pada PT Wilmar Cahaya Indonesia Tbk (CEKA) tahun 2014. Variabel size perusahaan memiliki jumlah sampel sebesar 55 data, dengan nilai minimum sebesar 26.53 pada PT Sekar Laut Tbk (SKLT) tahun 2014 dan sebesar 32.20 pada PT Indofood Sukses Makmur Tbk (INDF) tahun 2018. Variabel struktur modal memiliki jumlah sampel sebesar 55 data, dengan nilai minimum sebesar 0.16 pada PT Ultrajaya Milk Industry and Trading Company Tbk (ULTJ) tahun 2018 dan sebesar 3.03 pada PT Multi Bintang Indonesia Tbk (MLBI) tahun 2014.

\section{Hasil uji asumsi klasik}

Uji asumsi klasik dalam penelitian ini telah memenuhi seluruh syarat bahwa data dapat digunakan sebagai alat ukur.

\section{Uji normalitas}

Uji normalitas digunakan dalam model regresi yang akan menunjukkan sebaran data terdistribusi secara normal atau tidak dengan menggunkan grafik histogram, normal probability plot (P-P Plot), dan Kolmogorov-Smirnov Test.

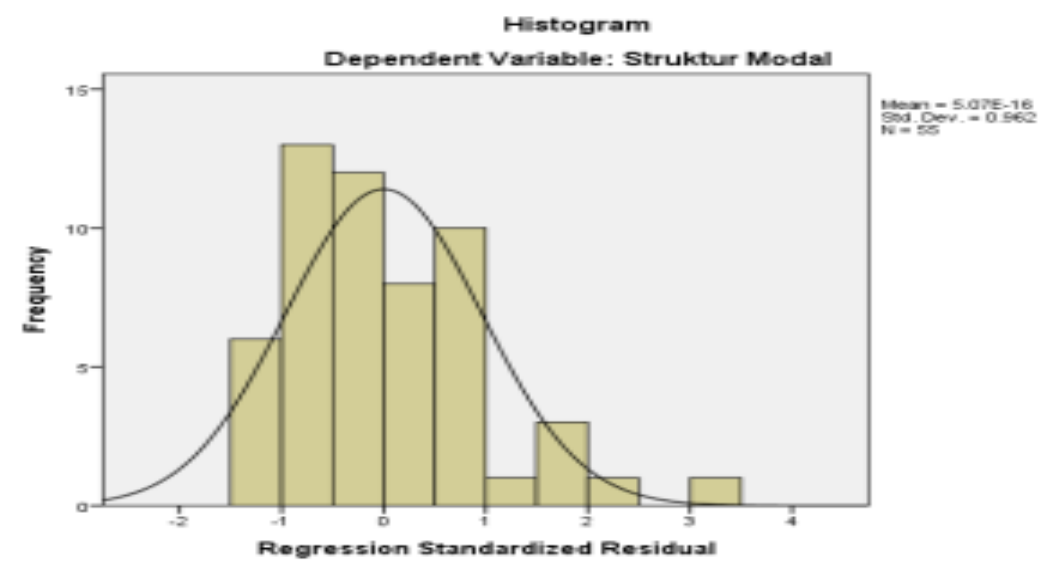

Gambar 2. Uji normalitas dengan histogram 
Pada Gambar 2 menunjukkan bahwa garis kurva tidak memiliki kecenderungan terjadinya kemiringan (skewness) atau garis kurva cenderung simetri (U), maka disimpulkan bahwa data terdistribusi secara normal.

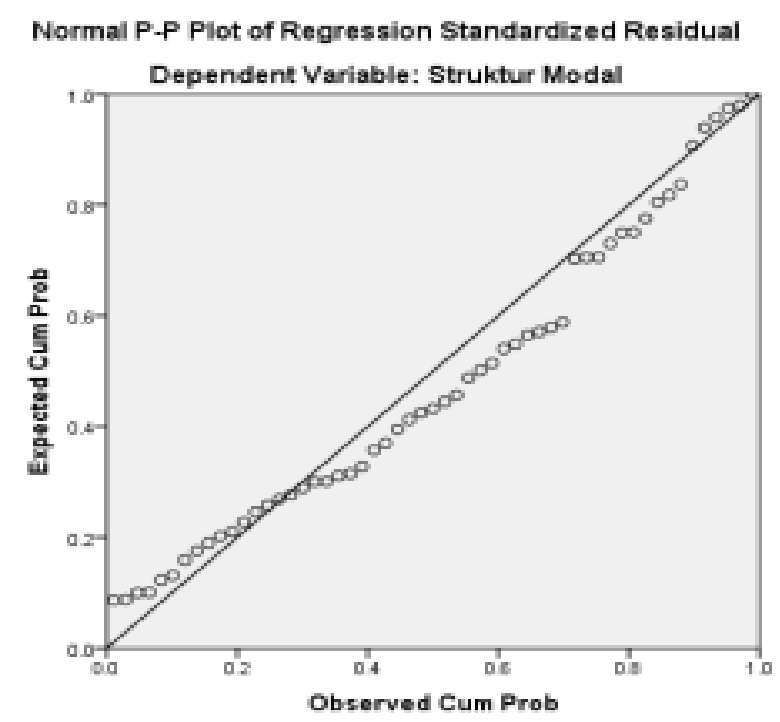

Gambar 3. Uji normalitas dengan normal probability plot (P-P Plot)

Pada Gambar 4. menunjukkan bahwa seluruh sebaran data tidak menyebar jauh pada garis diagonal atau mengkuti arah garis diagonal, sehingga dapat disimpulkan bahwa sebaran data terdistribusi secara normal.

Tabel 9. Hasil uji normalitas dengan kolmogorov-smirnov test

\begin{tabular}{llr}
\hline & & $\begin{array}{c}\text { Unstandardized } \\
\text { residual }\end{array}$ \\
\hline $\mathrm{N}$ & Mean & 55 \\
Normal parameters $^{\mathrm{a}, \mathrm{b}}$ & Std. deviation & $0 \mathrm{E}-7$ \\
& Absolute & .42529500 \\
Most extreme differences & Positive & .117 \\
& Negative & .117 \\
Kolmogorov-smirnov Z & & -.079 \\
Asymp. sig. (2-tailed) & & .871 \\
a. Test distibution & .434
\end{tabular}
a. Test distribution is Normal.
b. Calculated from data.

Sumber: Data diolah, 2020

Pada Tabel 9. menunjukkan hasil Kolmogorov-Smirnov Test bahwa seluruh data variabel penelitian, yaitu variabel struktur aktiva, profitabilitas, pertumbuhan penjualan, size perusahaan, dan struktur modal memiliki nilai signifikan (Asymp. Sig. (2-tailed) sebesar $0.434>0.05$, sehingga dapat disimpulkan bahwa data terdistribusi secara normal pada model regresi. 


\section{Uji multikolinearitas}

Uji multikolinearitas digunakan untuk menguji dan mengetahui bahwa dalam model regresi terjadi korelasi (hubungan) antar variabel bebas dengan menggunakan nilai Tolerance dan nilia Variance Inflation Factor (VIF).

Tabel 10. Uji multikolinearitas

\begin{tabular}{|c|c|c|}
\hline \multicolumn{3}{|c|}{ Coefficients $^{\mathrm{a}}$} \\
\hline \multirow{2}{*}{ Model } & \multicolumn{2}{|c|}{ Collinearity statistics } \\
\hline & Tolerance & VIF \\
\hline (Constant) & & \\
\hline Struktur aktiva & .966 & 1.036 \\
\hline Profitabilitas & .942 & 1.062 \\
\hline Pertumbuhan penjualan & .946 & 1.057 \\
\hline Size perusahaan & .969 & 1.032 \\
\hline
\end{tabular}

a. Dependent variable: Struktur modal

Sumber: Data diolah, 2020

Pada Tabel 10 menunjukkan bahwa struktur aktiva, profitabilitas, pertumbuhan penjualan, dan size perusahaan memiliki nilai Tolerance di atas 0.10 dan nilai Variance Inflation Factor (VIF) di bawah 10, hasil tersebut dapat disimpulkan bahwa seluruh variabel bebas tidak mengalami korelasi (hubungan). Oleh karena itu, seluruh variabel bebas dapat memprediksi variabel terikat.

\section{Uji heterokedastisitas}

Model regresi yang tepat atau baik bila tidak terjadi heterokedastisitas. Uji heterokedastisitas dalam penelitian ini menggunakan scatterplot.

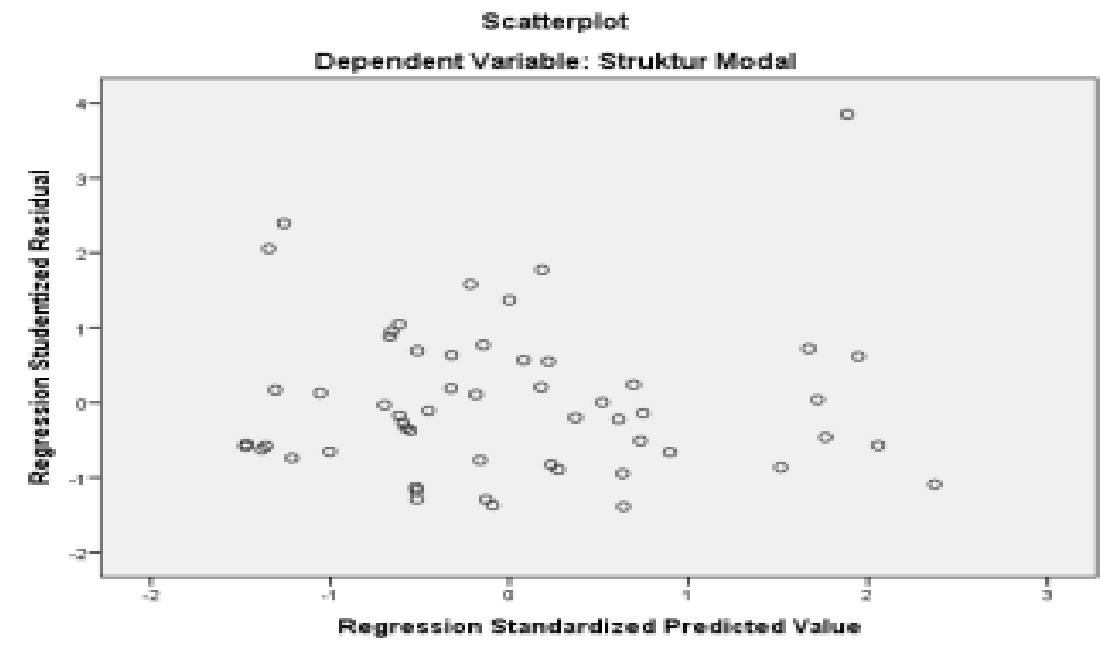

Gambar 4. Uji heterokedastisitas dengan scatterplot

Pada Gambar 4 menunjukkan bahwa data (titik-titik) adalah sebaran data dapat menyebar di atas dan di bawah angka 0 (nol) pada sumbu Y dan tidak membentu adanya pola tertentu, sehingga dapat disimpulkan dalam model regresi tidak terjadi heterokedastisitas.

\section{Uji autokorelasi}

Uji autokorelasi digunakan untuk data yang memiliki runtun waktu lebih dari satu tahun. Uji autokorelasi akan menunjukkan bahwa pada model regresi variabel terikat tidak mengalami korelasi terhadap nilai variabel terikat itu sendiri. 
Tabel 11. Uji autokorelasi

\begin{tabular}{l}
\hline \multicolumn{1}{c}{ Model summary $^{\mathbf{b}}$} \\
\hline Durbin-Watson \\
1.047 \\
\hline a. Predictors: (Constant), size perusahaan, pertumbuhan penjualan, struktur aktiva, \\
profitabilitas \\
b. Dependent variable: Struktur modal \\
Sumber: Data diolah, 2020
\end{tabular}

Pada Tabel 11 menunjukkan bahwa nilai Durbin-Watson (DW) digunakan dalam uji autokorelasi sebesar 1.047. Nilai Durbin-Watson (DW) berada di antara $-2<1.047$ $<+2$, yang dapat disimpulkan bahwa tidak terjadi autokorelasi dalam model regresi.

\section{Model penelitian}

Analisis regresi liniear berganda digunakan untuk menguji dan mengetahui arah hubungan variabel bebas terhadap variabel terikat.

Tabel 12. Regresi linear berganda

\section{Coefficients $^{\mathrm{a}}$}

\begin{tabular}{lcrcc}
\hline \multirow{2}{*}{ Model } & \multicolumn{2}{c}{ Unstandardized coefficients } & \multicolumn{2}{c}{$\begin{array}{c}\text { Standardized } \\
\text { coefficients }\end{array}$} \\
\cline { 2 - 4 } & \multicolumn{1}{c}{ B } & Std. error & Beta & \\
\hline (Constant) & -.076 & 1.206 & .580 \\
Struktur aktiva & 1.874 & .369 & .162 \\
Profitabilitas & .806 & .576 & .006 \\
Pertumbuhan & .030 & .548 & .020 \\
penjualan & .007 & .040 & \\
Size perusahaan & .040 & & \\
\hline
\end{tabular}

a. Dependent Variable: Struktur Modal

Sumber: Data diolah, 2020

Pada Tabel 12 menunjukkan bahwa memiliki persamaan regresi, yaitu: Struktur Modal $=-0.076+1.874$ Struktur Aktiva +0.806 Profitabilitas +0.030 Pertumbuhan Penjualan +0.007 Size Perusahaan $+\mathrm{e}$

\section{Pengujian hipotesis parsial (Uji t)}

Uji hipotesis parsial (uji t) digunakan untuk mengetahui pengaruh variabel bebas terhadap variabel terikat secara individual dengan membandingkan nilai $t_{\text {hitung }}$ dan $t_{\text {tabel. }}$. Nilai tabel pada alpha 5\% sebesar $2.008(\mathrm{df}=\mathrm{n}-(\mathrm{k}-1) ; \mathrm{df}=55-4 ; \mathrm{df}=51)$.

Tabel 13. Uji t

\section{Coefficients $^{\mathrm{a}}$}

\begin{tabular}{lcc}
\multicolumn{1}{r}{ Model } & t & Sig. \\
\hline (Constant) & & .0630 \\
Struktur aktiva & 5.085 & .000 \\
Profitabilitas & 1.400 & .168 \\
Pertumbuhan & .055 & .956 \\
penjualan & .176 & .861 \\
Size perusahaan & &
\end{tabular}

a. Dependent Variable: Struktur Modal

Sumber: Data diolah, 2020 
Variabel struktur aktiva terhadap variabel terikat memiliki nilai thitung sebesar 5.085 $>$ nilai $\mathrm{t}_{\text {tabel }}$ sebesar 2.008 dengan nilai signifikansi sebesar $0.000<$ alpha $(0.050)$, sehingga dapat disimpulkan struktur aktiva berpengaruh signifikan terhadap struktur modal.

Variabel profitabilitas terhadap variabel terikat memiliki nilai thitung sebesar $1.400<$ nilai $t_{\text {tabel }}$ sebesar 2.008 dengan nilai signifikansi sebesar $0.168>$ alpha $(0.050)$, sehingga dapat disimpulkan bahwa profitabilitas tidak berpengaruh signifikan terhadap struktur modal. Variabel pertumbuhan penjualan terhadap variabel terikat memiliki nilai $t_{\text {hitung }}$ sebesar 0.055 < nilai $t_{\text {tabel }}$ sebesar 2.008 dengan nilai signifikansi sebesar $0.956>$ alpha (0.050), sehingga dapat disimpulkan bahwa pertumbuhan penjualan tidak berpengaruh signifikan terhadap struktur modal.

Variabel size perusahaan terhadap variabel terikat memiliki nilai thitung sebesar $0.176<$ nilai $t_{\text {tabel }}$ sebesar 2.008 dengan nilai signifikansi sebesar $0.861>$ alpha $(0.050)$, sehingga dapat disimpulkan bahwa size perusahaan tidak berpengaruh signifikan terhadap struktur modal.

\section{Pengujian hipotesis simultan (uji F)}

Pengujian hipotesis simultan digunakan untuk menguji apakah dalam model regresi seluruh variabel bebas secara bersama-sama berpengaruh terhadap variabel terikat dengan membandingkan nilai $\mathrm{F}_{\text {hitung }}$ dan $\mathrm{F}_{\text {tabel. }}$ Nilai $\mathrm{F}_{\text {tabel }}$ pada alpha $5 \%$ sebesar $2.550(\mathrm{df} 1=\mathrm{k}-1)$; df $1=5-1 ; \mathrm{df} 1=4$ dan df $2=\mathrm{n}-\mathrm{k}$; df2 = 55-4; df2 = 51). Berdasarkan

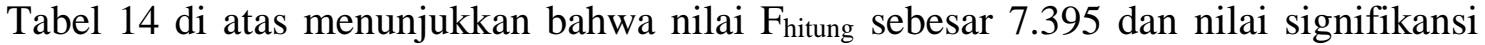
sebesar 0.000, yang berarti nilai $F_{\text {hitung }}$ sebesar $7.395>F_{\text {tabel }}$ sebesar 2.550 dengan nilai signifikans sebesar $0.000<$ alpha $(0.050)$, sehingga dapat disimpulkan bahwa struktur aktiva, profitabilitas, pertumbuhan penjualan, dan size perusahaan berpengaruh signifikan terhadap struktur modal.

Tabel 14. Uji F

\begin{tabular}{lrrrrr}
\hline Model & Sum of squares & df & \multicolumn{1}{c}{$\begin{array}{c}\text { Mean } \\
\text { square }\end{array}$} & F & Sig. \\
\hline Regression & 5.778 & 4 & 1.445 & 7.395 & $.000^{\mathrm{b}}$ \\
$\begin{array}{l}\text { Residual } \\
\text { Total }\end{array}$ & 9.767 & 50 & .195 & & \\
\hline
\end{tabular}

a. Dependent Variable: Struktur Modal

b. Predictors: (Constant), Size Perusahaan, Pertumbuhan Penjualan, Struktur Aktiva,

Profitabilitas

Sumber: Data diolah, 2020

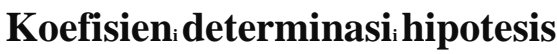

Koefisien determinasi digunakan untuk mengetahui kontribusi variabel bebas dalam mempengaruhi variabel terikat. Koefisien determinasi dalam penelitian ini menggunakan nilai Adjusted R-Square.

Tabel 15. Koefisien determinasi

\begin{tabular}{lccr}
\hline \multicolumn{4}{c}{ Model summary $^{\mathbf{b}}$} \\
\hline Model & $\mathrm{R}$ & $\mathrm{R}$ square & Adjusted R square \\
1 & $.610^{\mathrm{a}}$ & .372 & .321 \\
\hline a. & Predictors: (Constant), size perusahaan, pertumbuhan penjualan, struktur aktiva, \\
\multicolumn{3}{c}{ profitabilitas } \\
b. Dependent variable: Struktur modal & & \\
Sumber: Data diolah, 2020 &
\end{tabular}


Berdasarkan Tabel 15 menunjukkan bahwa koefisien determinasi dengan nilai Adjusted $R$-Square sebesar 0.321, yang memiliki arti variasi variabel struktur modal dapat dijelaskan oleh variabel struktur aktiva, profitabilitas, pertumbuhan penjualan, dan size perusahaan sebesar $32.1 \%$ sementara 67.9 adalah pengaruh dari variabel yang tidak dimasukan dalam penelitian ini.

\section{Pengaruh struktur aktiva terhadapstruktur modal}

Berdasarkan hasil uji hipotesis parsial menunjukkan nilai $t_{\text {hitung }}$ sebesar $5.085>$ nilai $t_{\text {tabel }}$ sebesar 2.008 dengan nilai signifikansi sebesar $0.000<$ alpha $(0.050)$, hasil tersebut menunjukkan bahwa struktur aktiva berpengaruh signifikan terhadap struktur modal pada Perusahaan Makanan dan Minuman di Bursa Efek Indonesia. Hasil penelitian selaras dengan Kartika (2009) bahwa struktur aktiva berpengaruh terhadap struktur modal.

\section{Pengaruh profitabilitas terhadap struktur modal}

Berdasarkan hasil uji hipotesis parsial menunjukkan nilai thitung sebesar $1.400<$ nilai $t_{\text {tabel }}$ sebesar 2.008 dengan nilai signifikansi sebesar $0.168>$ alpha $(0.050)$, hasil tersebut menunjukkan bahwa profitabilitas tidak berpengaruh signifikan terhadap struktur modal pada Perusahaan Makanan dan Minuman di Bursa Efek Indonesia. Hasil penelitian selaras dengan Alvareza dan Topowijono (2017) bahwa profitabilitas tidak berpengaruh terhadap struktur modal.

\section{Pengaruh pertumbuhan penjualan terhadap struktur modal}

Berdasarkan hasil uji hipotesis parsial menunjukkan nilai thitung sebesar $0.055<$ nilai $t_{\text {tabel }}$ sebesar 2.008 dengan nilai signifikansi sebesar $0.956>$ alpha $(0.050)$, hasil tersebut menunjukkan bahwa pertumbuhan penjualan tidak berpengaruh signifikan terhadap struktur modal pada Perusahaan Makanan dan Minuman di Bursa Efek Indonesia. Hasil penelitian selaras dengan Kartika (2016) bahwa pertumbuhan penjualan tidak berpengaruh terhadap struktur modal.

\section{Pengaruh size terusahaan terhadap struktur modal}

Berdasarkan hasil uji hipotesis parsial menunjukkan nilai thitung sebesar 0.176 < nilai $t_{\text {tabel }}$ sebesar 2.008 dengan nilai signifikansi sebesar $0.861>$ alpha $(0.050)$, hasil tersebut menunjukkan bahwa struktur aktiva, profitabilitas, pertumbuhan penjualan, dan size perusahaan berpengaruh signifikan terhadap struktur modal pada Perusahaan Makanan dan Minuman di Bursa Efek Indonesia. Hasil penelitian selaras dengan Naibaho, dkk (2015) bahwa ukuran perusahaan tidak berpengaruh terhadap struktur modal.

Pengaruh struktur aktiva, profitabilitas, pertumbuhan penjualan, dan size perusahaan terhadap struktur modal

Berdasarkan hasil uji hipotesis simultan menunjukkan nilai $F_{h i t u n g}$ sebesar 7.395 dan nilai signifikansi sebesar 0.000, yang berarti nilai $F_{\text {hitung }}$ sebesar $7.395>$ $F_{\text {tabel }}$ sebesar 2.550 dengan nilai signifikansi sebesar $0.000<$ alpha (0.050), hasil tersebut menunjukkan bahwa size perusahaan tidak berpengaruh signifikan terhadap struktur modal pada Perusahaan Makanan dan Minuman di Bursa Efek Indonesia.

\section{KESIMPULAN DAN SARAN}

\section{Kesimpulan}

Hasil uji hipotesis parsial diperoleh bahwa struktur aktiva berpengaruh signifikan terhadap struktur modal. Sedangkan, profitabilitas, pertumbuhan penjualan, dan size 
perusahaan tidak berpengaruh signifikan terhadap struktur modal. Hasil uji hipotesis simultan diperoleh bahwa struktur aktiva, profitabilitas, pertumbuhan penjualan, dan size perusahaan berpengaruh signifikan terhadap struktur modal.

Hasil koefisien determinasi dengan nilai Adjusted $R$-Square diperoleh bahwa $32.1 \%$ kontribusi struktur aktiva, profitabilitas, pertumbuhan penjualan, dan size perusahaan dalam mempengaruhi struktur modal.

\section{Saran}

Bagi perusahaan disarankan agar memperhatikan tingkat utang, aset, perolehan laba, dan tingkat penjualan perusahaan pada periode tertentu, yang dapat digunakan sebagai rujukan dalam menilai tingkat pengembalian terhadap modal yang telah ditanamkan, sehingga akan mampu mempengaruhi keputusan investor untuk melakukan investasi.

Bagi peneliti berikutnya dapat menambah faktor-faktor yang lebih potensial dalam mempengaruhi struktur modal, serta menambah tahun pengamatan agar hasil yang diperoleh semakin kompleks.

\section{DAFTAR PUSTAKA}

Alvareza, Argi., \& Topowijono.(2017). Analisisi pengaruhi ukuran perusahaan, profitabilitas, dan pertumbuhan perusahaan terhadap struktur modal (studi pada perusahaan food and beverages yang terdaftar di BEI 2012-2015). Jurnal Administrasi Bisnis. (JAB), 50(4), 77-85

Brigham, Eugene dan Houston, Joel F. (2015). Dasar-dasar Manajemen Keuangan. Salemba Empat: Jakarta

Joni dan Lina. (2010). Faktor-faktor yang mempengaruhi struktur modal. Jurnal Bisnis dan Akuntansi, 12 (2), 81-96

Juliandi, Azuar. 2013. Metodologi penelitian kuantitatif untuk ilmu-ilmu bisnis. M2000: Medan

Kartika, Andi.(2009).Faktor-faktor yang mempengaruhi struktur modal pada perusahaan manufaktur yang go public di BEI. Jurnal Dinamika Keuangan dan Perbankan, $1(2), 105-122$

Kartika, Andi. (2016). Pengaruh profitabilitas, struktur aset, pertumbuhan penjualan, dan ukuran perusahaan terhadap struktur modal perusahaan manufaktur di Bursa Efek Indonesia. Jurnal AMIK JTC | INFOKAM, 12(2), 49-58

Kasmir. (2013). Analisis Laporan Keuangan. Rajawali Pers: Jakarta

Laga, Maria Petronella Gladyse Rayza. (2016). Pengaruh struktur aktiva, pertumbuhan penjualan, ukuran perusahaan dan profitabilitas terhadap struktur modal pada perusahaan manufaktur di bursa efek Indonesia. Artikel Ilmiah, Sekolah Tinggi Ilmu Ekonomi Perbanas Surabaya: Surabaya.

Maryanti, Eny. (2016). Analisis profitabilitas, pertumbuhan perusahaan, pertumbuhan penjualan, dan struktur aktiva terhadap struktur modal pada perusahaan sektor industri barang konsumsi yang terdaftar di Bursa Efek Indonesia (Studi empiris pada perusahaan manufaktur yang terdaftar di bursa efek Indonesia Tahun 20122014). Riset Akuntansi dan Keuangan Indonesia (REAKSI), 1(2), 143-151

Naibaho, Andreas., Topowijono., dan Azizah, Devi Farah. (2015). Pengaruh profitabilitas, pertumbuhan penjualan, struktur aktiva, dan ukuran perusahaan terhadap struktur modal (Studi kasus pada perusahaan property and real estate yang terdaftar di BEI Tahun 2011-2013). Jurnal Administrasi Bisnis (JAB), 28(1), $131-142$

Niresh, J.i Aloy dan Velnampy, T. (2014). Firm Size and profitability: a study of listed manufacturing firms in Sri Lanka. International Journal of Business and Management, 9(4), 57-64 
Priambodo, Taruna John., Topowijono., dan Azizah, Devi Farah. (2014). Pengaruh struktur aktiva, tingkat pertumbuhan penjualan dan profitabilitas terhadap struktur modal (Studi pada perusahaan Tekstil dan Garmen yang listing di BEI periode 2010-2012). Jurnal Administrasi Bisnis (JAB), 9(1), 57- 64

Riyanto, Bambang. (2010). Dasar-dasar Pembelanjaan Perusahaan. BPFE Yogyakarta: Yogyakarta

Sawir, Agnes. (2005). Kebijakan pendanaan dan restrukturisas perusahaan. Gramedia Pustaka Utama: Jakarta

Sekartaji, Jenny, and Lena Farida. (2017). Pengaruh ukuran perusahaan dan growth terhadap leverage pada sub sektor keramik porselin dan kaca yang terdaftar di Bursa Efek Indonesia (BEI) Periode 2009-2010. Jurnal Online Mahasiswa Fakultas Ilmu Sosial dan Ilmu Politik Universitas Riau, 4(2), 1-15.

Swastha, Basu dan Handoko, Hani. (2011). Manajemen Pemasaran Analisis Perilaku Konsumen. BPFE: Yogyakarta

Zuliani, Selly. (2014). Pengaruh profitabilitas, pertumbuhan penjualan, likuiditas, struktur aset, dan tingkat pertumbuhan terhadap struktur modal. Skripsi. Sekolah Tinggi Ilmu Ekonomi Indonesia (STIESIA) Surabaya: Surabaya 